\title{
Mobile-Learning Potential Effects on Teachers' Initial Professional Development in Cameroon: Curriculum Perspective
}

\author{
Eric Len-Kibinkiri \\ Department of Science of Education, Higher Teachers' Training College Yaounde, University of Yaounde I, \\ Yaounde, Cameroon \\ Email: kibinkirieric@yahoo.com
}

Received 17 May 2014; revised 22 June 2014; accepted 30 June 2014

Copyright (C) 2014 by author and Scientific Research Publishing Inc. This work is licensed under the Creative Commons Attribution International License (CC BY). http://creativecommons.org/licenses/by/4.0/ c) (i) Open Access

\section{Abstract}

This study examines the relationship between mobile-learning and teachers' initial professional development in Cameroon, more specifically the relationship between access to telephone resources and teachers' professional development, use of multimedia telephone and teachers' professional development, mobile-learning environment and teachers' professional development. The incessant penetration of mobile phones in schools, and the need for a teaching strategy that can help institutions address their learning problems motivated the researcher to carry out this study. In order to proceed, three hypotheses were formulated to guide the study. A survey of two hundred (200) student-teachers drawn from three (3) primary government teacher training colleges and three higher teacher training colleges was carried out. Data were collected using a questionnaire. Pearson correlation coefficient, t-test and mediated regression were used to analyse the research hypotheses. Findings revealed that $\mathbf{m}$-learning has a significant influence on teachers' initial professional development. Results further suggest that attitude towards learning with a multimedia telephone has a direct impact on teachers' professional development. Based on these findings, recommendations are made to teacher education institutions and education stake-holders to develop a positive attitude towards m-learning, redefined their interaction strategies, above all, adopt teaching and learning strategies that are innovative, dynamic and multidimensional.

\section{Keywords}

Mobile-Learning, Blended Learning, Professional Development, Curriculum Perspective 


\section{Introduction}

The Cameroon government places a lot of importance on the education of her citizens. Nevertheless, education is a fundamental human right. The citizen's right to education is embodied in the constitution of the country, the Universal Declaration of Human Rights of 1948, the United Nations charter and the United Nation Organisation Convention on the Rights of the child that the country has ratified (The Constitution of the Republic of Cameroon, 1996). The Law of Orientation of Education in Cameroon (1998) seeks to promote quality education and the teaching of Information and Communication Technologies (ICTs) in schools. UNESCO and UNICEF (2012: 42) support that quality education does not only ensure every child's right to access education but also improves cognitive skills, promotes attitudes, values and other non-cognitive traits that are considered essential for the wellbeing of individuals, societies and nations.

Notwithstanding, this is the era in which mobile devices like telephones are taking the centre stage in almost every sector of life in Cameroon. The penetration of mobile phones in the educational sector has led to new concerns about the quality of education, the appropriateness of the curriculum, pedagogic resources, and innovative delivery methods such as electronic-learning, blended learning and mobile-learning. Ministry of Economy, Planning and Regional Development (2009: 26) states that the objective of Cameroon as concerns telephone is to multiply by five the number of telephone lines and increase mobile telephone network coverage in the country. The government has also engaged in a number of projects to promote access to the Internet and its facilities.

It is worthy to note that mobile phones pose a great challenge to so many teachers as well as students. Telephones have potentials to improve the quality of teaching and learning as well as harbour a threat to education if poorly used. What is most disturbing is the fact that Cameroon is unable to take full advantage of these technologies in the educational sector. World Bank (2006: 4) as well as Jimenez, Kiso and Ridao-Cano (2007: 20) remark that despite enormous progress made in educational outcomes, there are still many young people who lack the basic skills needed for work and life in most developing countries. The teaching and learning environment in most schools in Cameroon is unattractive and provides little or no access to learning resources. This is typical of regions considered as education priority zones like the Northern Regions of Cameroon and Bakassi in the South West Region. Schools in these areas lack electricity, computers and Internet. Where few computers exist, there are no specialists trained to cater for these technologies. Teachers sent to such schools find teaching a very frustrating activity. They find it difficult to teach ICTs or to integrate in subject teaching. Thus there is a great need for an alternative strategy to teaching ICTs or integration of ICTs in subject teaching in Cameroon schools.

\section{Conceptual Framework}

\subsection{Mobile-Learning (M-Learning)}

Latchem (2012: 12) states that m-learning involves the use of handheld or wearable technologies, thus making learning accessible virtually everywhere. Traxler and Kukulska-Hulme (2005: 5) points out that, m-learning devices are lightweight and handheld, including: Personal Digital Assistants (PDAs), handheld computers, mobile phones also called cell phones. Bakari et al. (2009: 17) postulate that mobile devices can provide almost all the services that were provided by the stationary personal computers in the past. Traxler and Kukulska-Hulme (2005: 5) point out that the University of Wolverhampton in the United Kingdom uses mobile devices to support staff and disadvantaged students in teaching, learning and administration.

\subsection{Blended Learning}

Latchem (2012: 13) asserts that blended learning combines the traditional “classroom” or "face-to-face” methods of teaching and learning with mobile-learning to achieve the most appropriate mix of presentation, interaction and "hands-on" learning. Noe (2002: 263) defines blended learning as "the use of a combination of online learning, face-to-face instruction, and other methods for distributing learning content and instruction”. A survey of traditional and blended learning at the National University of Rwanda carried out by Rwagasana and Stucki (2009: 67) show that many traditional lecturers prefer the use of the blended learning approach.

As far as this work is concern, m-learning is an alternative and innovative strategy or model of teaching and learning which involve access to telephone resources, use of telephone resources and telephone learning environment. Electronic applications involved include multimedia phones and the Internet. Teachers' initial professional development (TPD) refers to the acquisition of basic skills and competences necessary for effective 
teaching. In this study, it includes teachers' didactic relations; stakeholder relations; and attitude towards learning with multimedia telephone. A didactic relation is defined in this work as the relationship between the studentteacher and other pedagogic relations, for example the relationship between the student-teacher and the established relationship between the student and the content. Stakeholder relations refers to the relationship between the student-teacher and all the stakeholders in the learning environment, for example, the relationship between the student-teacher and the principal, discipline department, counselling department, health department, parents and community resource persons. Attitude towards learning with multimedia telephone refers to the kind of mind set adopted by the student-teacher towards m-learning.

\section{Theoretical Framework}

The main theories that form the basis of this study include socio-constructivism and the cultural theory. Socioconstructivism became influential in education through the works of Lev Vygotsky. According to Tu (2000: 33), Vygotsky's theory, "full cognitive development requires social interaction". Students construct knowledge through social interaction with others. M-learning has the capacity to help students create their own knowledge through social interaction. In Vygotsky's theory, the teacher serves as a facilitator and guide rather than director and builder of learning. Indeed, Vygotsky's work showed that a child's cognition and thinking, to a great extent, relied upon the manipulation of material objects used as tools as well as societal surroundings. It is worthy to note that Lev Vygotsky's views of learning have influenced the growth of the cultural approach to instruction. The cultural view frames intelligent action as something that is mediated (Crook, 2001: 19). A favourable environment or good conditions for learning to the cultural approach is one in which the learner is granted access to complete versions of what is to be acquired rather than starting at a distance, and incrementally moving forward as is the case with behaviourism (Crook, 2001: 22). Tchombe (2004: 338) concludes that "how learning occurs and is supported has implications for the level of participation and the quality of the end product".

A lot of research has been carried out on the future potentials of ICTs in the development process. But little is known about m-learning. In order to proceed, the following research hypotheses were formulated to guide the study:

\subsection{General Research Hypotheses}

There is a significant relationship between mobile-learning and teachers' initial professional development.

\subsection{Specific Research Hypotheses}

\section{Hypotheses 1}

Alternative Hypotheses: Access to telephone resources has a significant influence on teachers' professional development.

\section{Hypotheses 2}

Alternative Hypotheses: The use of multimedia telephone has a significant influence on teachers' professional development.

\section{Hypotheses 3}

Alternative Hypotheses: Mobile-learning environment has a significant influence on teachers' professional development.

\section{Research Methodology}

This study was carried out in general Government Teacher Training Colleges in Cameroon. Cameroon is subdivided in to ten regions (North West, South West, West, Littoral, Centre, South, East, Adamawa, North and Far North). Each region is further subdivided into divisions and subdivisions. The country has 59 Government Teacher Training Colleges that trains teachers of basic education located in Sub-Divisions. It also has eight state Universities. Five of these universities have Higher Teacher Training institutions that train teachers of secondary education in both technical and general education. The researcher employed survey research design. The use of survey necessitated the study of a representation sample, which allowed the researcher to make inferences and generalizations to the population under study. It also permitted the collection of quantitative data.

To obtain a representative sample for this study, a number of sampling techniques were employed. Firstly, 
purposive sampling was used to select the target population. The researcher being a lecturer in one of the target institution (Higher Teacher Training College Yaounde) used his own personal judgment to select the level and classes that he believed would provide data needed for the study based on prior experiences and knowledge of ICTs. Secondly, cluster sampling was applied. The various regions/teacher education institutions of the country were considered as clusters. The researcher wrote the names of the different regions and institutions respectively on a slip of paper. The slips were then folded and put in a basket. The folded slips in the basket were thoroughly shuffled. After shuffling, each slip was blindly drawn. A drawn slip was unfolded and the selected region/institution recorded. After that, the slip was folded and put back in to the basket for another reshuffling, drawing and recording. A recorded slip drawn the second time was not taken in to account. Instead of being recorded, it was again folded and put back in to the basket for another reshuffling, drawing and recording. This procedure was repeated until the desired number of regions and institutions was selected. The procedure gave each region and school an equal chance of being selected.

The operation above led to the selection of three (3) primary Government Teacher Training Colleges (GTTC Yaounde, GTTC Buea, GTTC Bamenda) and three (3) Higher Teacher Training Colleges (HTTC Yaounde, FED University of Buea, HTTC Bambili-Bamenda) from three (3) regions of the country. After selecting the schools with their respective levels, the number of student-teachers to be selected from each institution to make up the desired sample size was calculated. This number was proportional to the total number of student-teachers in each school selected. Finally, the researcher employed the procedure described above in smaller classes (using simple random sampling) to obtain the sample size of 200 respondents initially desired for this study (see Table 1).

As shown in the table, of the 200 respondents, 140 were made up of females scoring a percentage of (70\%) while 60 were made up of males scoring a percentage of (30\%). Data were collected using a questionnaire that was carefully designed with respect to the variables under study. The instrument consisted of seven (7) sections (Sections $\mathrm{A}, \mathrm{B}, \mathrm{C}, \mathrm{D}, \mathrm{E}, \mathrm{F}$ and $\mathrm{G}$ ) designed to examine "the potential relationship between mobile-learning and teachers' initial professional development in Cameroon: Curriculum Perspective”. In Section A, demographic information (school type, name of school, region and gender) was requested from the respondents. Sections B, C, D, E, F and G of the instrument sought to measure the respondent's knowledge of m-learning and teachers' initial professional development. A four point-Likert scale questions was provided with 4 representing strongly agree and 1 representing strongly disagree. Section $B$ of the instrument relates to accessibility of mobile phones. Section $C$ focused on the use of mobile phones. Section $D$ sought to measure the respondent's understanding of mobile-learning environments. Section $E$ was designed to assess the respondent's view about mobile phones and didactic relations. Section $F$ sought to measure respondent's opinion about mobile phones and stakeholder relations in school. Section $G$ was designed to assess respondent's attitudes towards learning with mobile devices. Pearson correlation coefficient, t-test and mediated regression were used to analyse the research hypotheses.

\section{Presentation of Findings and Discussions}

\subsection{Research Hypotheses 1: Access to Telephone Resources Has a Significant Influence on Teachers' Professional Development}

The first research hypothesis $\left(\mathrm{RH}_{1}\right)$ claims that access to telephone resources has a significant influence on teachers' professional development. As shown in Table 2, the results of the correlation between access to tele-

Table 1. Summary table of sample population according to region.

\begin{tabular}{ccc}
\hline REGION & SCHOOL & SAMPLE \\
\hline CENTRE & HTTC Yaounde & 30 \\
& GTTC Yaounde & 45 \\
SOUTH WEST & FED University of Buea & 20 \\
NORTH WEST & GTTC Buea & 40 \\
Grand Total & HTTC Bambili-Bamenda & 25 \\
\hline
\end{tabular}


Table 2. Correlation between access to telephone resources and teachers’ professional development.

\begin{tabular}{|c|c|c|c|c|}
\hline & & & 1 & 2 \\
\hline \multirow{3}{*}{1} & \multirow{3}{*}{ Access to telephone resources } & Pearson Correlation & 1 & $0.304^{* * *}$ \\
\hline & & Sig. (2-tailed) & & 0.000 \\
\hline & & $\mathrm{N}$ & 200 & 200 \\
\hline \multirow{3}{*}{2} & \multirow{3}{*}{ Teachers' professional development } & Pearson Correlation & $0.304^{* * *}$ & 1 \\
\hline & & Sig. (2-tailed) & 0.000 & \\
\hline & & $\mathrm{N}$ & 200 & 200 \\
\hline
\end{tabular}

Note: ${ }^{* * *}$ Correlation is significant at the 0.01 level (2-tailed).

phone resources and teachers' professional development show that $\mathrm{r}(200)=0.304,(p<0.001)$. From this result, conclusions made were that access to telephone resources has a significant influence on teachers' professional development. The magnitude of the effect was verified by the test-value which gave a coefficient of determination of 0.0924 , which means that $9.24 \%$ of the variability of teachers' professional development could be explained by access to telephone resources.

Also, when the responses of the student-teachers on the questionnaire in relation to access to telephone resources were scored and categorised, it was observed that all the items (prices of multimedia phones are affordable, it is easy to get multimedia phones, the cost of telephone is decreasing everywhere) categorised under accessibility were very important to the respondents considering the slight differences in the means and standard deviations.

\subsection{Research Hypotheses 2: The Use of Multimedia Telephone Has a Significant Influence on Teachers' Professional Development}

The second research hypothesis $\left(\mathrm{RH}_{2}\right)$ asserts that the use of multimedia telephones has a significant influence on teachers' professional development. As shown in Table 3, findings of the correlation between the use of multimedia telephones and teachers' professional development show that $\mathrm{r}(200)=0.304$, $(p<0.001)$. From this result, inference made was that the use of multimedia telephones has a significant influence on teachers' professional development. The test-value gave a coefficient of determination of 0.093 , which means that $9.30 \%$ of the variability of teachers' professional development is explained by the use of multimedia telephones.

Moreover, when the responses of the student-teachers on the questionnaire in relation to the use of multimedia telephones were scored and categorised, it was observed that all the items (multimedia phone is convenient, it is easy to use a multimedia phone, multimedia phone is user friendly, the telephone is portable, the telephone has a lower power consumption, telephones operate from batteries and solar energy) categorised under usability were very important to the respondents considering the slight differences in the means and standard deviations.

\subsection{Research Hypotheses 3: Mobile-Learning Environment Has a Significant Influence on Teachers' Professional Development}

The third research hypothesis $\left(\mathrm{RH}_{3}\right)$ asserts that mobile-learning environment has a significant influence on teachers' professional development. As shown in Table 4, the results of the correlation between mobile-learning environment and teachers' professional development show that $\mathrm{r}(200)=0.281,(p<0.001)$. From this finding, inference made was that mobile-learning environments have a significant influence on teachers' professional development. The test-value gave a coefficient of determination of 0.079 , which means that $7.90 \%$ of the variability of teachers' professional development could be explained by mobile-learning environment.

Also, the results of the survey reveal that all the items on the questionnaire (telephone offers access to unlimited information, there is flexibility in a telephone based learning environment, telephone based learning environment offers storage facilities, video representations in a telephone enhances learning, pictorial representation in a telephone enhances learning, audio presentations in a telephone sustains learning, text presentation in a telephone is user friendly) categorised under telephone learning environment were very important to the respondents considering the slight differences in the means and standard deviations. 
Table 3. Correlation between the use of multimedia telephone and teachers' professional development.

\begin{tabular}{|c|c|c|c|c|}
\hline & & & 1 & 2 \\
\hline \multirow{3}{*}{1} & \multirow{3}{*}{ The use of multimedia telephone } & Pearson Correlation & 1 & $0.305^{* * *}$ \\
\hline & & Sig. (2-tailed) & & 0.000 \\
\hline & & $\mathrm{N}$ & 200 & 200 \\
\hline \multirow{3}{*}{2} & \multirow{3}{*}{ Teachers' professional development } & Pearson Correlation & $0.305^{* * *}$ & 1 \\
\hline & & Sig. (2-tailed) & 0.000 & \\
\hline & & $\mathrm{N}$ & 200 & 200 \\
\hline
\end{tabular}

Notes: $\mathrm{N}=200,{ }^{* * *} p<0.001$.

Table 4. Correlation between mobile-learning environment and teachers' professional development.

\begin{tabular}{|c|c|c|c|c|}
\hline & & & 1 & 2 \\
\hline \multirow{3}{*}{1} & \multirow{3}{*}{ Mobile-learning environment } & Pearson Correlation & 1 & $0.281^{* * *}$ \\
\hline & & Sig. (2-tailed) & & 0.000 \\
\hline & & $\mathrm{N}$ & 200 & 200 \\
\hline \multirow{3}{*}{2} & \multirow{3}{*}{ Teachers' professional development } & Pearson Correlation & $0.281^{* * * *}$ & 1 \\
\hline & & Sig. (2-tailed) & 0.000 & \\
\hline & & $\mathrm{N}$ & 200 & 200 \\
\hline
\end{tabular}

Notes: $\mathrm{N}=200,{ }^{* * *} p<0.001$.

\subsection{Variability of Teachers' Professional Development in Relation to Gender}

The analysis of Means reveals that gender did not have a significant influence on teachers' professional development (see Table 5). However, on the average, the reported variability of the Mean of teachers' professional development was higher for male student-teachers $(\mathrm{M}=3.1328$, $\mathrm{SE}=0.344)$ than for female student-teachers $(\mathrm{M}=3.1089, \mathrm{SE}=0.407), \mathrm{t}(198)=0.397, p>0.05$. Inference made was that teachers' professional development does not vary according to gender.

\subsection{Mediation of Attitude towards Learning with Telephone on Access to Telephone Resources and Teachers' Professional Development}

The mediation analysis reveals a total mediation of attitude towards learning with telephone on access to telephone resources and teachers' professional development (see Table 6). Access to telephone resources predicts significantly attitude towards learning with telephone $(\beta=0.433, \mathrm{t}(198)=6.764, p=0.000)$, and teachers' professional development $(\beta=0.304, \mathrm{t}(198)=4.493, p<0.001)$. Also, attitude towards learning with telephone predicts significantly teachers' professional development $(\beta=0.817, \mathrm{t}(198)=20.082, p<0.001)$.

As shown in Figure 1, When the effect of attitude towards learning with telephone is controlled, the relation between access to telephone resources and teachers' professional development turn out to be insignificant $(\beta=$ $-0.062, t(198)=-1.381, p=0.169), 95 \%$ CI $[-0.082,0.015]$.

\subsection{Mediation of Attitude towards Learning with Telephone on the Use of Multimedia Telephone and Teachers' Professional Development}

The mediation analysis reveals a total mediation of attitude towards learning with telephone on the use of multimedia telephone and teachers’ professional development (see Table 7). The use of multimedia telephone predicts significantly attitude towards learning with telephone $(\beta=0.422, \mathrm{t}(198)=6.548, p=0.000)$, and teachers' professional development $(\beta=0.305, \mathrm{t}(198)=4.504, p<0.001)$. Also, attitude towards learning with telephone predict significantly teachers’ professional development $(\beta=0.817, \mathrm{t}(198)=20.082, p<0.001)$. 
Table 5. Effect of gender on teachers’ professional development.

\begin{tabular}{ccccccccc}
\hline & Gender & $\mathbf{N}$ & Mean & Std. Deviation & Std. Error Mean & Df & t & $\boldsymbol{p}$ \\
\hline $\begin{array}{c}\text { Teachers' } \\
\text { professional } \\
\text { development }\end{array}$ & Male & 60 & 3.1328 & 0.34446 & 0.04447 & & & \\
\hline
\end{tabular}

Notes: $\mathrm{N}=200, p>0.05$.

Table 6. Analysis of Mediation of attitude towards learning with telephone on access to telephone resources and teachers' professional development.

\begin{tabular}{|c|c|c|c|c|c|}
\hline & B & SE B & Std. B & $\mathbf{T}$ & Sig. \\
\hline \multicolumn{6}{|c|}{ Condition 1} \\
\hline \multicolumn{6}{|c|}{ Regression equation: $\mathrm{Y}=2.585+0.166 \mathrm{X}\left(\mathrm{N}=200 ; \mathrm{R}^{2}=0.093 ;\right.$ Adjusted $\left.\mathrm{R}^{2}=0.088\right)$} \\
\hline (Constant) & 2.585 & 0.121 & & 21.360 & 0.000 \\
\hline Access to telephone resources (X) & 0.166 & 0.037 & $0.304^{* * *}$ & 4.493 & 0.000 \\
\hline \multicolumn{6}{|c|}{ Condition 2} \\
\hline \multicolumn{6}{|c|}{ Regression equation: $\mathrm{M}=2.137+0.268 X\left(\mathrm{~N}=200 ; \mathrm{R}^{2}=0.188 ;\right.$ Adjusted $\left.\mathrm{R}^{2}=0.184\right)$} \\
\hline (Constant) & 2.137 & 0.130 & & 16.420 & 0.000 \\
\hline Access to telephone resources (X) & 0.268 & 0.040 & $0.433^{* * *}$ & 6.764 & 0.000 \\
\hline \multicolumn{6}{|c|}{ Condition 3} \\
\hline \multicolumn{6}{|c|}{ Regression equation: $\mathrm{Y}=0.957+0.720 \mathrm{M}\left(\mathrm{N}=200 ; \mathrm{R}^{2}=0.671 ;\right.$ Adjusted $\left.\mathrm{R}^{2}=0.669\right)$} \\
\hline (Constant) & 0.957 & 0.109 & & 8.807 & 0.000 \\
\hline Attitude towards learning with telephone (M) & 0.720 & 0.036 & 0.817 & 20.082 & 0.000 \\
\hline \multicolumn{6}{|c|}{ Condition 4} \\
\hline \multicolumn{6}{|c|}{ Regression equation: $\mathrm{Y}=0.995-0.034 \mathrm{X}+0.744 \mathrm{M}\left(\mathrm{N}=200 ; \mathrm{R}^{2}=0.674 ;\right.$ Adjusted $\left.\mathrm{R}^{2}=0.671\right)$} \\
\hline (Constant) & 0.995 & 0.112 & & 8.897 & 0.000 \\
\hline Access to telephone resources (X) & -0.034 & 0.025 & -0.062 & -1.381 & 0.169 \\
\hline Attitude towards learning with telephone (M) & 0.644 & 0.040 & 0.706 & 16.739 & 0.000 \\
\hline
\end{tabular}

Notes: ${ }^{* * *} p<0.001$.

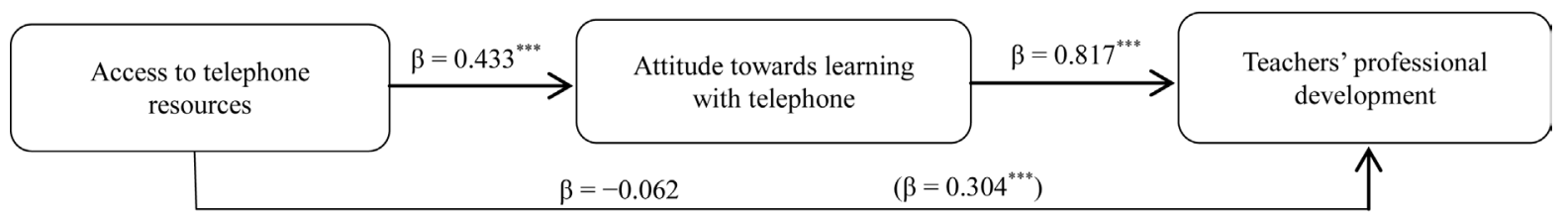

Notes: ${ }^{* * *} p<0.001$.

Figure 1. Total mediation of attitude towards learning with telephone on access to telephone resources and teachers' professional development.

As shown in Figure 2, when the effect of attitude towards learning with telephone is controlled, the relation between the use of multimedia telephone and teachers' professional development becomes insignificant $(\beta=$ $-0.049, \mathrm{t}(198)=-1.101, p=0.272), 95 \%$ CI $[-0.090,0.025]$.

\subsection{Mediation of Attitude towards Learning with Telephone on Mobile-Learning Environment and Teachers' Professional Development}

The mediation analysis reveals a total mediation of attitude towards learning with telephone on mobile-learning 
Table 7. Analysis of Mediation of attitude on the use of multimedia telephone resources and teachers' professional development.

\begin{tabular}{|c|c|c|c|c|c|}
\hline & B & SE B & Std. B & $\mathbf{T}$ & Sig. \\
\hline \multicolumn{6}{|c|}{ Condition 1} \\
\hline \multicolumn{6}{|c|}{ Regression equation: $\mathrm{Y}=2.450+0.198 \mathrm{X}\left(\mathrm{N}=200 ; \mathrm{R}^{2}=0.093 ;\right.$ Adjusted $\left.\mathrm{R}^{2}=0.088\right)$} \\
\hline (Constant) & 2.450 & 0.150 & & 16.311 & 0.000 \\
\hline Use of multimedia telephone $(\mathrm{X})$ & 0.198 & 0.044 & $0.305^{* * *}$ & 4.504 & 0.000 \\
\hline \multicolumn{6}{|c|}{ Condition 2} \\
\hline \multicolumn{6}{|c|}{ Regression equation: $\mathrm{M}=1.949+0.312 \mathrm{X}\left(\mathrm{N}=200 ; \mathrm{R}^{2}=0.422 ;\right.$ Adjusted $\left.\mathrm{R}^{2}=0.178\right)$} \\
\hline (Constant) & 1.949 & 0.163 & & 11.990 & 0.000 \\
\hline Use of multimedia telephone $(\mathrm{X})$ & 0.312 & 0.048 & $0.422^{* * *}$ & 6.548 & 0.000 \\
\hline \multicolumn{6}{|c|}{ Condition 3} \\
\hline \multicolumn{6}{|c|}{ Regression equation: $\mathrm{Y}=0.957+0.720 \mathrm{M}\left(\mathrm{N}=200 ; \mathrm{R}^{2}=0.671 ;\right.$ Adjusted $\left.\mathrm{R}^{2}=0.669\right)$} \\
\hline (Constant) & 0.957 & 0.109 & & 8.807 & 0.000 \\
\hline Attitude towards learning with telephone (M) & 0.720 & 0.036 & $0.817^{* * *}$ & 20.082 & 0.000 \\
\hline \multicolumn{6}{|c|}{ Condition 4} \\
\hline \multicolumn{6}{|c|}{ Regression equation: $\mathrm{Y}=1.010-0.032 \mathrm{X}+0.739 \mathrm{M}\left(\mathrm{N}=200 ; \mathrm{R}^{2}=0.673\right.$; Adjusted $\left.\mathrm{R}^{2}=0.669\right)$} \\
\hline (Constant) & 1.010 & 0.119 & & 8.500 & 0.000 \\
\hline Use of multimedia telephone $(\mathrm{X})$ & -0.032 & 0.029 & -0.049 & -1.101 & 0.272 \\
\hline Attitude towards learning with telephone (M) & 0.739 & 0.040 & $0.840^{* * *}$ & 18.681 & 0.000 \\
\hline
\end{tabular}

Notes: ${ }^{* * *} p<0.001$.

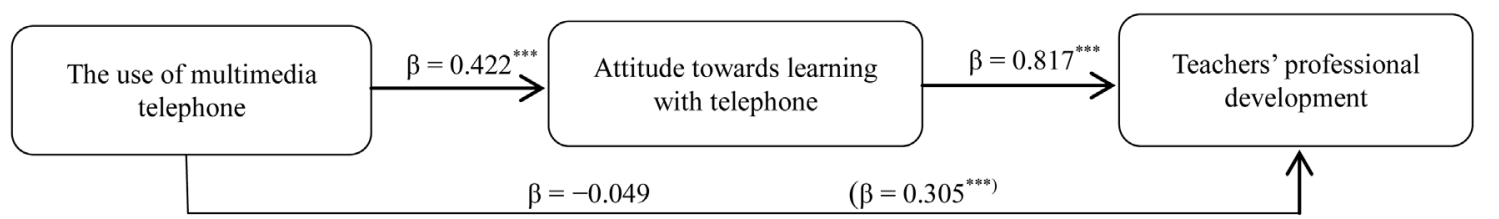

Notes: ${ }^{* * *} p<0.001$.

Figure 2. Total mediation of attitude towards learning with telephone on the use of multimedia telephone resources and teachers' professional development.

environment and teachers’ professional development (see Table 8). Mobile-learning environment predicts significantly attitude towards learning with telephone $(\beta=0.317, \mathrm{t}(198)=4.871, p=0.000)$, and teachers' professional development $(\beta=0.281, \mathrm{t}(198)=4.116, p<0.001)$. Also, attitude towards learning with telephone predict significantly teachers' professional development $(\beta=0.817, \mathrm{t}(198)=20.082, p<0.001)$.

As shown in Figure 3, when the effect of attitude towards learning with telephone is controlled, the relation between mobile-learning environment and teachers' professional development turn out to be insignificant $(\beta=$ $0.014, \mathrm{t}(198)=0.333, p=0.739), 95 \%$ CI $[-0.045,0.063]$.

\section{Summary of Results}

Figure 4 shows total mediation between attitude towards learning with telephone and access to telephone resources, the use of multimedia telephone, mobile-learning environment and teachers' professional development (TPD). The challenge to improving teachers' initial competences is to develop a positive attitude towards mlearning (learning with telephone). However, to facilitate such improvements, student-teachers and teachers al- 
Table 8. Analysis of mediation of attitude towards learning with telephone on mobile-learning environment and teachers' professional development.

\begin{tabular}{|c|c|c|c|c|c|}
\hline & B & SE B & Std. B & $\mathbf{T}$ & Sig. \\
\hline \multicolumn{6}{|c|}{ Condition 1} \\
\hline \multicolumn{6}{|c|}{ Regression equation: $\mathrm{Y}=2.517+0.176 \mathrm{X}\left(\mathrm{N}=200 ; \mathrm{R}^{2}=0.079 ;\right.$ Adjusted $\left.\mathrm{R}^{2}=0.074\right)$} \\
\hline (Constant) & 2.517 & 0.148 & & 17.020 & 0.000 \\
\hline Mobile-learning environment (X) & 0.176 & 0.043 & $0.281^{* * * *}$ & 4.116 & 0.000 \\
\hline \multicolumn{6}{|c|}{ Condition 2} \\
\hline \multicolumn{6}{|c|}{ Regression equation: $\mathrm{M}=2.203+0.234 \mathrm{X}\left(\mathrm{N}=200 ; \mathrm{R}^{2}=0.107 ;\right.$ Adjusted $\left.\mathrm{R}^{2}=0.102\right)$} \\
\hline (Constant) & 2.203 & 0.166 & & 13.313 & 0.000 \\
\hline Mobile-learning environment (X) & 0.234 & 0.048 & $0.327^{* * *}$ & 4.871 & 0.000 \\
\hline \multicolumn{6}{|c|}{ Condition 3} \\
\hline \multicolumn{6}{|c|}{ Regression equation: $\mathrm{Y}=0.957+0.720 \mathrm{M}\left(\mathrm{N}=200 ; \mathrm{R}^{2}=0.671 ;\right.$ Adjusted $\left.\mathrm{R}^{2}=0.669\right)$} \\
\hline (Constant) & 0.957 & 0.109 & & 8.807 & 0.000 \\
\hline Attitude towards learning with telephone (M) & 0.720 & 0.036 & 0.817 & 20.082 & 0.000 \\
\hline \multicolumn{6}{|c|}{ Condition 4} \\
\hline \multicolumn{6}{|c|}{ Regression equation: $\mathrm{Y}=0.939+0.009 \mathrm{X}+0.716 \mathrm{M}\left(\mathrm{N}=200 ; \mathrm{R}^{2}=0.671 ;\right.$ Adjusted $\left.\mathrm{R}^{2}=0.668\right)$} \\
\hline (Constant) & 0.939 & 0.122 & & 7.694 & 0.000 \\
\hline Mobile-learning environment (X) & 0.009 & 0.027 & 0.014 & 0.333 & 0.739 \\
\hline Attitude towards learning with telephone (M) & 0.716 & 0.038 & 0.814 & 18.825 & 0.000 \\
\hline
\end{tabular}

Notes: ${ }^{* * *} p<0.001$.

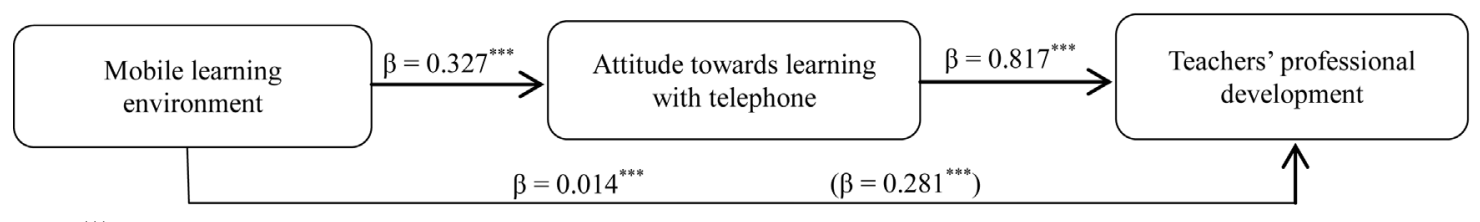

Notes: ${ }^{* * *} p<0.001$.

Figure 3. Total mediation of attitude towards learning with telephone on mobile-learning environment and teachers' professional development.

ready in the field must have certain prerequisites. These include access to telephone resources, the use of multimedia telephone, and a comfortable mobile-learning environment.

Figure 4 shows that access to telephone resources, use of multimedia telephone, and a comfortable mobilelearning environment are three complementary aspects of mobile-learning as a developmental function for teachers' professional growth. Figure 4 also shows that access, use and mobile-learning environment need to be accompanied by attitude towards learning with mobile technologies. It integrates the three (3) variables (access, use and mobile-learning environment) and unifies mobile-learning with attitude to promote teachers' professional development (TPD). This model makes mobile-learning and TPD a pragmatic goal. It demonstrates that attitude towards learning with multimedia telephone has a direct impact on TPD. Results of hypotheses one (1) have shown that access to telephone resources has a significant influence on TPD. Findings of hypotheses two (2) revealed that the use of multimedia telephone has a significant influence on TPD. Findings of Hypothesis three (3) have shown that mobile-learning environment has a significant influence on TPD. This means of delivery holds great promise for bridging the digital divide because mobile devices are far more common and cheaper than computers in developing and middle-income countries. 


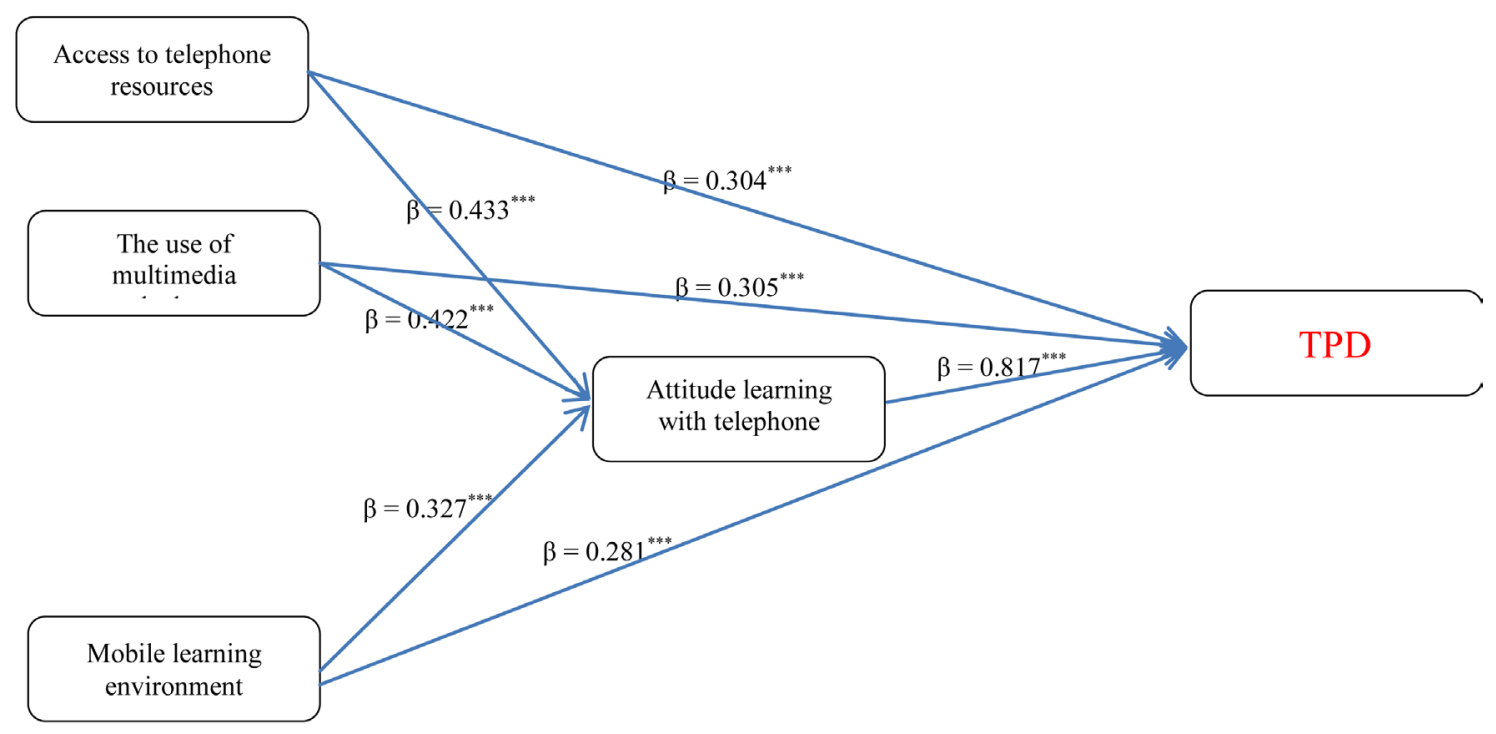

Figure 4. Mobile-learning potential effects on teachers’ professional development.

\section{Conclusion and Recommendations}

In conclusion, findings of this study have revealed that m-learning has a significant influence on teachers' initial professional development. Results have also shown that access to a telephone, the use of a multimedia phone and mobile-learning environments should be accompanied by the right attitude towards learning with mobile technologies in order to promote teachers' professional development. Thus, attitude towards learning with a multimedia telephone has a direct consequence on teachers' professional development. This study offers new evidence as well that institutions of learning most especially teacher training institutions can adopt m-learning as an alternative strategy for quality education. Based on the findings of this study and given that m-learning is still a new teaching and learning strategy in Cameroon and Africa as a whole, recommendations are made to teacher education institutions, students, lecturers and the government to develop a positive attitude towards m-learning. Teachers need to redefine their interaction strategies with education stakeholders with respect to m-learning. Student-teachers need to acquire effective didactic skills while in training schools in order to be able to do their job effectively when they graduate. Teacher education institutions should get into partnership with telecommunication companies like MTN, ORANGE, and CAMTEL MOBILE so that they can offer their services at subsidized rates to students and lecturers. In-service training should be given to lecturers on m-learning for capacity building. The government should furnish teacher training colleges with Information and Communication Infrastructure. The government should establish genuine partnerships with international bodies like the World Bank, UNESCO, and UNICEF amongst others involved in knowledge generation, dissemination and capacity building to develop attractive and sustainable ICT based learning programmes. Finally, given the state of Information and Communication Infrastructure in schools, the researcher suggests that a similar study should be carried out using the experimental research design to validate these results.

\section{References}

Bakari, J. K., Ishaq, M. A., Miyedu, C., Nykvist, B., \& Deutschmann, M. (2009). Enhancement of In-Service Teachers Training Programme through Mobile Phones in Tanzania. eLearning Africa 2009: 4th International Conference on ICT for Development, Education and Training, 17-19.

Crook, C. (2001). The Social Character of Knowing and Learning: Implications of Cultural Psychology for Educational Technology. Journal of Information Technology for Teacher Education, 10, 19-36.

Jimenez, E., Kiso, N., \& Ridao-Cano, C. (2007). Educational Second Chances for Youth. Development Outreach, 9, $20-21$.

Latchem, C. (2012). Quality Assurance Tolkit for Open and Distance Non-Formal Education.

Ministry of Economy, Planning and Regional Development (2009). Cameroon Vision 2035.

Rwagasana, G., \& Stucki, P. (2009). Strategic options and Results of Introducing Blended Learning at the National Univer- 
sity of Rwanda. eLearning Africa 2009: 4th International Conference on ICT for Development, Education and Training, 66-69.

Tchombe, T. M. (2004). Psychological Parameters in Teaching. Yaoundé: Presses Universitaires d Afrique.

The Constitution of the Republic of Cameroon (1996). Law Number 96-06 of 18th January 1996.

The Law of Orientation of Education in Cameroon (1998). Law Number 98/004 of 14th April 1998: To Lay down Guidelines on Education in Cameroon.

Traxler, J., \& Kukulska-Hulme, A. (2005). Mobile Learning in Developing Countries.

Tu, C.-H. (2000). On-Line Learning Migration: From Social Learning Theory to Social Presence Theory in a CMC Environment. Journal of Network and Computer Application, 23, 27-37. http://dx.doi.org/10.1006/jnca.1999.0099

UNESCO and UNICEF (2012). EFA GOAL 6: Quality Education. Bangkok: UNESCO, UNICEF EAPRO and UNICEF ROSA.

World Bank (2006). From Schooling Access to Learning Outcomes: An Unfinished Agenda. Washington D.C.: The World Bank. 
Scientific Research Publishing (SCIRP) is one of the largest Open Access journal publishers. It is currently publishing more than 200 open access, online, peer-reviewed journals covering a wide range of academic disciplines. SCIRP serves the worldwide academic communities and contributes to the progress and application of science with its publication.

Other selected journals from SCIRP are listed as below. Submit your manuscript to us via either submit@scirp.org or Online Submission Portal.
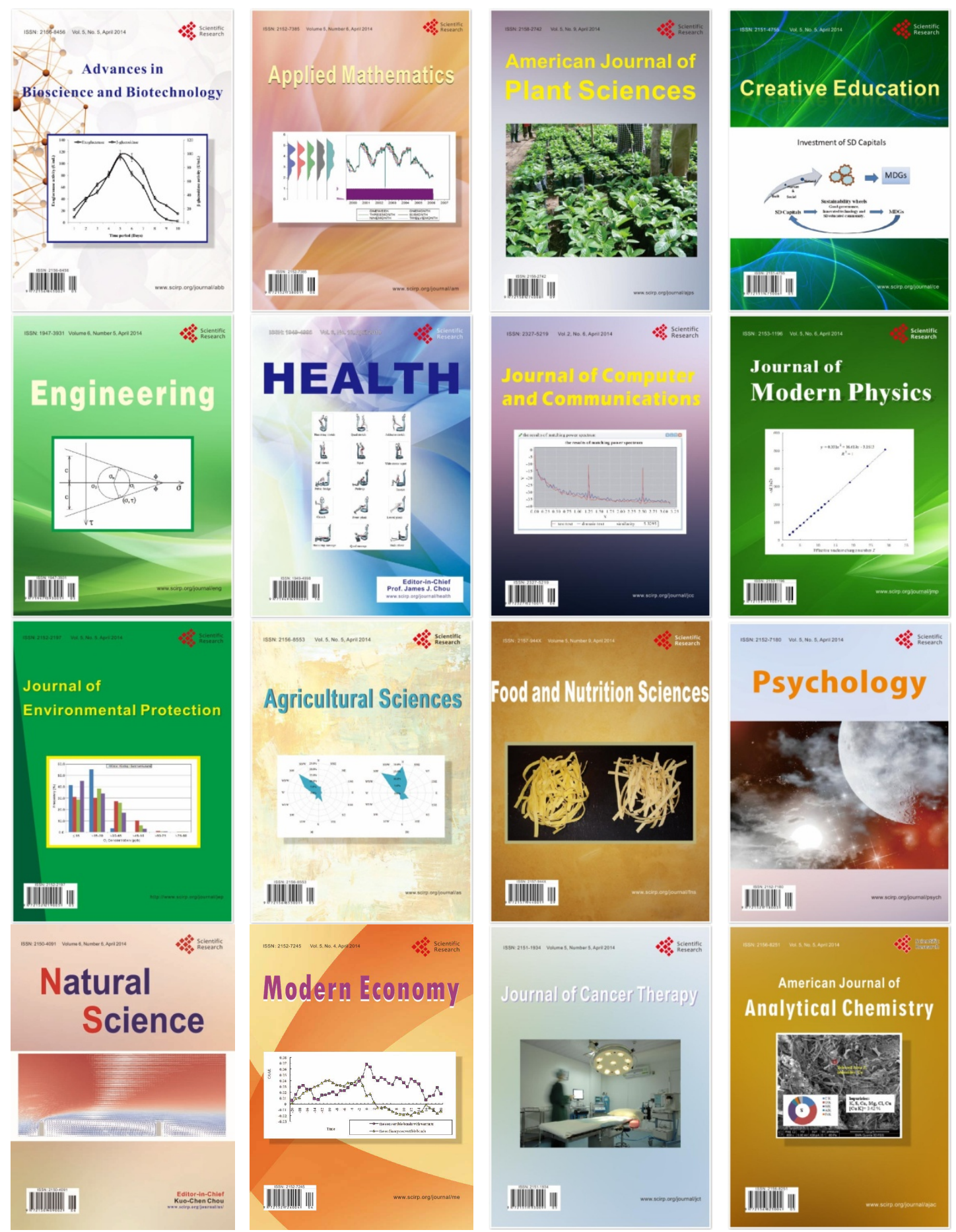